\title{
THE EFFECT OF DOPAMINE, ATROPINE, PHENYLEPHRINE AND CARDIAC PACING ON OXYGEN CONSUMPTION DURING FENTANYL-NITROUS OXIDE ANAESTHESIA IN THE DOG
}

\author{
Dwayne R. Westenskow, Jay K. Huffaker and Theodore H. Stanley
}

\begin{abstract}
In animals deeply anaesthetized with fentanyl and nitrous oxide the artierial blood pressure and heart rate were increased using dopamine, atropine, electrical pacing and phenylephrine in order to study the accompanying change in whole body oxygen consumption. Seven dogs (16-24 kg) were anaesthetized with fentanyl $1 \mu \mathrm{g} \cdot \mathrm{kg}^{-1} \cdot \mathrm{min}^{-1}$. After completing instrumentation a dopamine infusion was started at a rate of $39 \mu \mathrm{g} \cdot \mathrm{kg}^{-1} \cdot \mathrm{min}^{-1}$. After the mean blood pressure reached $18.6 \mathrm{kPa}$ the infusion was reduced to $10 \mu \mathrm{g} \cdot \mathrm{kg}^{-1} \cdot \mathrm{min}^{-1}$ and maintained for 10 minutes. After waiting 45 minutes an infusion of atropine $20 \mu \mathrm{g} \cdot \mathrm{kg}^{-1} \cdot \mathrm{min}^{-1}$ was started and when the heart rate reached $120 \mathrm{~b} / \mathrm{min}$ the infusion was slowed to $1.25 \mu \mathrm{g} \cdot \mathrm{kg}^{-1} \cdot \mathrm{min}^{-1}$ and maintained for 10 minutes. Twenty-five minutes later the heart rate was increased to 150 beats/min and maintained at that level for 10 minutes using electrical pacing. The pacing was removed and an infusion of phenylephrine $5 \mu \mathrm{g} \cdot \mathrm{kg}^{-1} \cdot \mathrm{min}^{-1}$ was started. When the blood pressure reached $21.3 \mathrm{kPa}$ the infusion was reduced to $2.5 \mu \mathrm{g} \cdot \mathrm{kg}^{-1} \cdot \mathrm{min}^{-1}$ and maintained for 10 minutes. The results show increases in oxygen consumption of 14 per cent with dopamine, 19 per cent with atropine, 16 per cent with pacing, and 14 per cent with phenylephrine. All changes were significantly different from the control values. The magnitude of change in whole body oxygen consumption was best predicted by either the cardiac output $x$ blood pressure product or by the cardiac output alone.
\end{abstract}

KEY WORDS: OXYGEN, consumption, whole body; HEART, oxygen consumption; dopamine; atropine, phenylephrine pacing.

General anaesthesia is usually associated with a decrease in whole body oxygen consumption $\left(\dot{V}_{2}\right) \cdot{ }^{1-7} \mathrm{~A}$ significant part of this reduction in $\dot{\mathrm{V}}_{2}$ has been attributed to decreases in myocardial work and myocardial oxygen consumption $\left(\mathrm{MVO}_{2}\right) .{ }^{6.7}$ As two main determinants of $\mathrm{MVO}_{2}$ are arterial blood pressure and heart rate, it seems that if blood pressure or heart rate are raised pharmacologically during anaesthesia, that $\dot{\mathrm{VO}}_{2}$ will increase. In this study both arterial blood pressure and heart rate were increased using dopamine, atropine, electrical pacing and phenylephrine and the accompanying changes in the whole body $\mathrm{Vo}_{2}$ were measured.

\section{Methods and Materials}

Seven mongrel dogs (16-24 kg) were anaesthetized with thiopentone $25 \mathrm{mg} \cdot \mathrm{kg}^{-1}$ intraven-

Dwayne R. Westenskow, Ph.D., Assistant Professor of Anesthesiology; Jay K. Huffaker, M.E., Graduate Student, Bioengineering; Theodore H. Stanley, M.D., Professor of Anesthesiology: Department of Anesthesiology, University of Utah Medical Center, 50 North Medical Drive, Salt Lake City, Utah 84123, U.S.A.

Canad. Anaesth. Soc. J., vol. 28, no. 2, March 1981 ously, had their trachea intubated with a cuffed tracheal tube and were ventilated with 50 per cent nitrous oxide with oxygen. Mechanical ventilation was adjusted to maintain arterial $\mathrm{PCO}_{2}$ at 5.05 $\pm 0.67 \mathrm{kPa}$ ( $38 \pm 5$ torr). A continuous intravenous infusion of fentanyl citrate 0.005 per cent at the rate of $1.0 \mu \mathrm{g} \cdot \mathrm{kg}^{-1} \cdot \mathrm{min}^{-1}$ was started in an extremity. This infustion rate was sufficient to produce a deep level of anaesthesia. Muscle relaxation was achieved using an intravenous bolus of succinylcholine $1 \mathrm{mg} \cdot \mathrm{kg}^{-1}$ followed by a continuous infusion of succinylcholine $0.01 \mathrm{mg} \cdot \mathrm{kg}^{-1} \cdot \mathrm{min}^{-1}$. Oesophageal temperature was monitored with a Yellow Springs temperature probe placed in the lower half of the oesophagus. Temperature was maintained at 39 $\pm 1^{\circ} \mathrm{C}$ using warming blankets. A 20 gauge catheter was passed through a small groin incision into the femoral artery and threaded to the aortic arch for blood pressure and blood gas monitoring. Cardiac output was calculated by computer analysis of the central arterial pressure wave as described by Warner and co-workers. ${ }^{8}$ Arterial $\mathrm{PCO}_{2},\left[\mathrm{H}^{+}\right](\mathrm{pH})$ and $\mathrm{PO}_{2}$, were measured 121 
TABLE I

Cardiovascular Parameters (mean \pm standard deviation) During Control and During Dopamine, Atropine, and Phenylephrine Infusions and During Pacing

\begin{tabular}{lcccc}
\hline & $\begin{array}{c}\text { Heart Rate } \\
(/ \mathrm{min})\end{array}$ & $\begin{array}{c}\text { Mean Blood } \\
\text { Pressure } \\
(\mathrm{kPa})\end{array}$ & $\begin{array}{c}\text { Cardiac } \\
\text { Output } \\
(1 / \mathrm{min})\end{array}$ & $\begin{array}{c}\text { Oxygen } \\
\text { Consumption } \\
(\mathrm{ml} / \mathrm{min})\end{array}$ \\
\hline Control & $75 \pm 17$ & $12.8 \pm 2.7$ & $1.9 \pm 0.9$ & $166 \pm 43$ \\
Dopamine & $65 \pm 11$ & $19.0 \pm 2.8^{*}$ & $3.2 \pm 1.0^{*}$ & $188 \pm 56^{*}$ \\
Atropine & $135 \pm 13^{*}$ & $19.2 \pm 3.5^{*}$ & $4.0 \pm 1.8^{*}$ & $198 \pm 53^{*}$ \\
Pacing & $150 \pm 14^{*}$ & $16.5 \pm 3.9^{*}$ & $3.0 \pm 1.4^{*}$ & $193 \pm 46^{*}$ \\
Phenylephrine & $72 \pm 21$ & $21.4 \pm 3.5^{*}$ & $2.2 \pm 0.3$ & $188 \pm 46^{*}$ \\
\hline
\end{tabular}

${ }^{*} \mathrm{P}<0.05$, Student's paired t-test when compared to control values.

body $\mathrm{V}_{2}$ was measured continuously using an oxiconsumeter prototype recently developed in this laboratory. ${ }^{9}$

After completing preparatory procedures control values for mean arterial blood pressure $(\overline{\mathrm{BP}})$, cardiac output (QT), heart rate (HR), and oxygen consumption $\left(\mathrm{VO}_{2}\right)$ were obtained by averaging measurements made every three minutes over a 10 minute period. A continuous intravenous infusion of dopamine $39 \mu \mathrm{g} \cdot \mathrm{kg}^{-1} \cdot \mathrm{min}^{-1}$ was started in a second peripheral vein. When $\overline{\mathrm{BP}}$ reached $18.6 \mathrm{kPa}$, the infusion rate was reduced to $10 \mu \mathrm{g} \cdot \mathrm{kg}^{-1} \cdot \mathrm{min}^{-1}$ and maintained for $10 \mathrm{~min}$ utes. The dopamine infusion was then stopped and 45 minutes were allowed for $\overline{\mathrm{BP}}$ to return to control values. A continuous intravenous infusion of atropine $20 \mu \mathrm{g} \cdot \mathrm{kg}^{-1} \cdot \mathrm{min}^{-1}$ was then started and continued until $H R$ reached 120 beats per minute. This increased heart rate was maintained with atropine $1.25 \mu \mathrm{g} \cdot \mathrm{kg}^{-1} \cdot \mathrm{min}^{-1}$ intravenously for 10 minutes. Following this, the atropine infusion was stopped and 25 minutes were allowed for HR to return to normal.

Heart rate was also increased by electrical pacing. This was accomplished by passing an 18 gauge needle through the chest into the left ventricular muscle. A nerve stimulator was used to pace the heart at 150 beats per minute for 10 minutes. The pacing stimulus was removed and an infusion of phenylephrine $5 \mu \mathrm{g} \cdot \mathrm{kg}^{-1} \cdot \mathrm{min}^{-1}$ was begun. When $\overline{\mathrm{BP}}$ reached $21.3 \mathrm{kPa}$, the infusion rate was reduced to $2.5 \mu \mathrm{g} \cdot \mathrm{kg}^{-1} \cdot \mathrm{min}^{-1}$ and maintained for 10 minutes.

The average value for each variable was found by averaging readings taken every two minutes during each 10 minute period of interest, Statistical difference from control was determined using student's paired t-test, comparing the control reading with the reading taken during drug infusion.

\section{RESUlTS}

Consistent increases in $\mathrm{V}_{2}$ were seen with infusion of atropine, dopamine and phenylephrine and with pacing. The results in Table I show increases in $\dot{V}_{2}$ of 14 per cent with dopamine, 19 per cent with atropine, 14 per cent with phenylephrine, and 16 per cent with pacing. All changes in $\dot{V}_{2}$ were statistically significant from the control level at the $p<0.05$ level. As heart rate was increased using atropine or pacing, $\overline{\mathrm{BP}}$ and $\mathrm{Q} T$ also increased significantly. Dopamine increased $\overrightarrow{\mathrm{BP}}$ and $\dot{Q} \mathrm{~T}$ but did not affect $\mathrm{HR}$. Phenylephrine increased $\overline{\mathrm{BP}}$ significantly.

When $\overline{\mathrm{BP}}$ alone was raised above control, as with dopamine and phenylephrine, $\dot{V}_{2}$ increased significantly. When HR and BP were both raised above control, as occurred with the infusion of atropine or with pacing, $\dot{V o}_{2}$ was raised four per cent higher than with dopamine or phenylephrine. The correlation coefficient between changes in $\mathrm{HR}$ and $\dot{\mathrm{V}}_{2}$ was 0.46 , between $\overline{\mathrm{BP}}$ and $\dot{V}_{\mathrm{O}_{2}} \mathrm{r}=0.40$, and between $Q \mathrm{~T}$ and $\dot{V}_{\mathrm{O}_{2}} \mathrm{r}=0.70$. The correlation coefficient between HR- $\overline{\mathrm{BP}}$ product and $\mathrm{VO}_{2}$ was 0.47 , and between $\mathrm{QT}-\overline{\mathrm{BP}}$ product and $\mathrm{V}_{2}$ was 0.66 .

\section{Discussion}

The results of this study demonstrate that infusions of dopamine, atropine, phenylephrine and electrical pacing during fentanyl anaesthesia can cause increases in whole body $\mathrm{VO}_{2}$ of 12-19 per cent. These changes accompanied significant changes in cardiac work due to increased heart rate, blood pressure and/or cardiac output.

Dopamine has its major cardiovascular effect on alpha- and beta- adrenergic receptors and is known to increase peripheral resistance at high 
infusion rates and to increase arterial blood pressure in animals. 10-12 These haemodynamic changes do not necessarily cause myocardial hypoxia. As myocardial work and $\mathrm{MVO}_{2}$ increase, myocardial blood flow may increase proportionately and myocardial ischaemia may be avoided.$^{13-14}$ Though this is not true for patients with cardiac disease, it is valid for most other patients.

In this study an infusion of dopamine $39 \mu \mathrm{g} \cdot \mathrm{kg}^{-1} \cdot \mathrm{min}^{-1}$ caused a 12 per cent increase in $\overline{\mathrm{BP}}$ and a 68 per cent increase in QT. These haemodynamic changes were accompanied by a 14 per cent increase in $\mathrm{VO}_{2}$. Large percentage increases in $\overline{\mathrm{BP}}$ and $\dot{\mathrm{QT}}$ are known to change myocardial work and $\mathrm{MVO}_{2}$ and may be a major source of the change in $\mathrm{VO}_{2}$ during dopamine infusion in this study.

The primary effect of atropine on the cardiovascular system is to increase heart rate by blocking vagal effects at the SA node. ${ }^{15}$ In this study atropine was infused to increase the heart rate from 65 to 135 beats per minute. $\overline{\mathrm{BP}}, \mathrm{Q} \mathrm{T}$ and $\mathrm{VO}_{2}$ increased by 50,110 and 19 per cent respectively.

Electrical pacing was used as a nonpharmacological method of altering heart rate. As the heart rate increased to 150 per minute the $\overline{\mathrm{BP}}$ and QT rose significantly and $\mathrm{VO}_{2}$ increased by 16 per cent. Electrical pacing and atropine had similar effects on $\overline{\mathrm{BP}}$ and $\mathrm{QT}$ and both increased $\mathrm{V}_{2}$ by similar amounts.

Phenylephrine is a powerful alpha receptor stimulant which causes a rise in systolic and diastolic blood pressure with little or no change in HR or QT. ${ }^{16}$ In this study phenylephrine was used to raise $\overline{\mathrm{BP}}$ to $21.3 \mathrm{kPa}$. HR and $\dot{\mathrm{Q}} \mathrm{T}$ did not change significantly; $\dot{\mathrm{V}}_{2}$ increased by 12 per cent.

The transition from light to deep levels of anaesthesia generally results in a decrease in whole body $\mathrm{VO}_{2}$ and a decrease in the cardiovascular parameters $\mathrm{HR}, \overrightarrow{\mathrm{BP}}$ and $\mathrm{QT}$. It has been shown that this decrease in $\mathrm{Vo}_{2}$ is mainly the result of decreased myocardial work and decreased $\mathrm{MVO}_{2},{ }^{17.18}$ To predict the increase or decrease in $\mathrm{MVO}_{2}$ from the cardiovascular parameters, investigators have used the rate pressure product, the area under the ventricular systolic pressure curve, the maximum velocity of myocardial isotonic shortening, etc. In studies using the anaesthetized dog, the product of $\mathrm{QT}_{\mathrm{T}}$ and $\overline{\mathrm{BP}}$ (myocardial external work) has proven quite useful. ${ }^{18}$
It is shown in this study that an increase in the cardiovascular parameters $\mathrm{HR}, \overline{\mathrm{BP}}$ and $Q \mathrm{~T}$ cause an increase in whole body $\mathrm{VO}_{2}$ even at a constant deep level of anaesthesia. Our data show a higher correlation between changes in whole body $\mathrm{VO}_{2}$ and the $\mathrm{QT} \times \overline{\mathrm{BP}}$ product $(\mathrm{r}=0.70)$ than between the $\mathrm{HR} \times \overline{\mathrm{BP}}$ product and $\mathrm{V}_{2}(r=0.40)$ suggesting that the $\mathrm{Q} \mathrm{r} \times \overline{\mathrm{BP}}$ product is a better prediction of increases in metabolic expenditure and work during deep levels of anaesthesia. The increase in whole body $\mathrm{VO}_{2}$ is also better predicted by increased $\mathrm{QT}$ than by increases in either $\mathrm{HR}$ or $\overline{\mathrm{BP}}$.

\section{SUMMARY}

The results of this study demonstrate statistically significant increases in whole body $\mathrm{VO}_{2}$ when dopamine, atropine, phenylephrine and pacing are administered during deep fentanylnitrous oxide anaesthesia. The magnitude of the change in $\mathrm{VO}_{2}$ was best predicted by either the cardiac output $x$ blood pressure product or by the cardiac output.

\section{REFERENCES}

1. Nunn, J.F. Applied Respiratory Physiology With Special Reference to Anaesthesia, 2nd ed. London, Butterworths (1969)

2. NGAI, S.H. \& PAPPER, E.M. Metabolic Effects of Anesthesia. Springfield, Charles C. Thomas (1962).

3. THEYE, R.A. Thiopental and oxygen consumption. Anesth. Analg. 49: (1970).

4. Rolly, G., Renders Versichelen, L. \& VaN DER, A.A. Oxygen consumption during enflurane (ethrane ${ }^{(8)}$ ) anesthesia. Acta Anaesth. Belg. No. 2: 246 (1974).

5. Nisbet, H.I.A., Dobbinson, T.L., Thomas, M.B. \& PELTON, D.A. Oxygen uptake in ventilated children during methoxyflurane anaesthesia. Canad. Anaesth. Soc. J. 20: 334 (1973).

6. Severinghaus, J.W. \& Cullen, S.C. Depression of myocardium and body oxygen consumption with fluothane. Anesthesiology 19: 165 (1968).

7. THEYe, R.A. The contributions of individual organ systems to the decrease in whole-body $\mathrm{VO}_{2}$ with halothane. Anesthesiology 37: 367 (1972).

8. Warner, H., Gardner, R. \& Toronto, A Computer-based monitoring of cardiovascular functions in post-operative patients. Circulation (Suppl. II) 37: 68-74 (1968).

9. WESTENSKOW, D.R., JohNSON, C.C., JoRdAN, W.S. et al. Instrumentation for continuous oxygen consumption of critically-ill and surgical patients IEEE. Trans. Biomed. Eng. 24: 331-337 (1977).

10. Daniel, H.B., Bagwell E.R., \& Walton, R.P. Limitation of myocardial function by reduced coronary blood flow during insporterenol action. Circ. Res. 21: 85 (1967).

11. Huckauf, H., Ramdohr, B. \& Shordee, R. 
Dopamine induced hypoxemia in patients with left heart failure. Int. J. Clin. Pharmacol. 14: 215 (1976).

12. McClenathan, J.H., Guyton, R.A., Breyer, R.H., Newman, G.E. \& Michaelis, L.L. The effects of isoproterenol and dopamine on regional myocardial blood flow after stenoisis of circumflex coronary artery. J. Thorac. and Cardiovas. Surg. 73: 43l (1977).

13. Crexell, C. Bourassa, M.G. \& Biron, P. Effects of dopamine on myocardial metabolism in patients with ischaemic heart disease. Cardiovas. Res. 7: 438 (1973).

14. Goodman, L.S. \& Gilman, A. The pharmacological Basis of Therapeutics, 4th ed. New York, Macmillan Co. (1970).
15. Dauchot, P. \& Gravenstein, J.S. Bradycardia after myocardial ischema and its treatment with atropine. Anesthesiology 44: 501 (1976).

16. Wood-Smith, F.G. \& S'rewart, H.C. Drugs in Anesthetic Practice. 2nd ed, Washington, Butterworths (1964).

17. Westenskow, D.R., Jordan, W.S., Hodges, M.R. \& STANLEY, T.H. Correlation of oxygen uptake and cardiovascular dynamics during $\mathrm{N}_{2} \mathrm{O}$. fentanyl and $\mathrm{N}_{2} \mathrm{O}$-thiopental anesthesia in the dog. Anesth. Analg. 57: 37 (1978).

18. THEYE, R.A. Myocardial and total oxygen consumption with halothane. Anesthesiology 28: 1042-1047 (1967).

\section{RÉSUMÉ}

L'on sait que l'anesthésie générale diminue la consommation d'oxygène et que ce phénomène serait attribuable en grande partie à une réduction du travail myocardique. Notre étude avait pour objet d'étudier l'influence d'une élévation de la fréquence cardiaque et de la pression artérielle sur la consommation d'oxygène chez le sujet anesthésié.

A cette fin, l'on a élevé la fréquence cardiaque et la pression artérielle d'animaux anesthésiés profondément au fentanyl, au moyen de dopamine, d'atropine, d'un pacing cardiaque ou de phényléphrine. Sept chiens de 16 à $24 \mathrm{~kg}$ ont été anesthésiés au fentanyl à la dose de $1 \mu \mathrm{g} \cdot \mathrm{kg}^{-1} \cdot \min ^{-1} \mathrm{et}$, après installation des moniteurs, on leur a administré une perfusion de dopamine à la dose de $39 \mu \mathrm{g} \cdot \mathrm{kg}^{-1} \cdot \min ^{-1}$ jusqu'à ce que leur pression moyenne soit de $18.6 \mathrm{kPa}$. La dose de cet agent était alors réduite à $10 \mu \mathrm{g} \cdot \mathrm{kg}^{-1} \cdot \mathrm{min}^{-1}$ durant les dix minutes suivantes. Après une attente de 45 minutes, on commençait une perfusion d'atropine à raison de $20 \mu \mathrm{g} \cdot \mathrm{kg}^{-1} \cdot \mathrm{min}^{-1} \mathrm{et}$, lorsque la fréquence cardiaque atteignait $120 / \mathrm{min}$, la perfusion était ralentie de façon à administrer $1.25 \mu \mathrm{g} \cdot \mathrm{kg}^{-1} \cdot \mathrm{min}^{-1}$ au cours des dix prochains minutes. Vingt-cinq minutes plus tard, la fréquence cardiaque était élevée à 150 par minute et maintenue à ce chiffre durant dix minutes au moyen d'un pace-maker. Le pacing était alors cessé et une perfusion de phényléphrine était commencée à la dose de $5 \mu \mathrm{g} \cdot \mathrm{kg}^{-1} \cdot \mathrm{min}^{-1}$. Lorsque la pression artérielle atteignait $21.3 \mathrm{kPa}$, la perfusion était réduite à $2.5 \mu \mathrm{g} \cdot \mathrm{kg}^{-1} \cdot \mathrm{min}^{-1}$ et maintenue à cette dose durant dix minutes.

On a trouvé que la consommation totale d'oxygène s'élevait de 14 pour cent avec la dopamine, de 19 pour cent avec l'atropine, de 16 pour cent avec le pacing à $150 \cdot \mathrm{min}^{-1}$ et de 14 pour cent avec le phényléphrine. Cette étude démontre donc qu'une élévation de la fréquence cardiaque, de la pression artérielle moyenne et du débit cardiaque élève la consommation globale d'oxygène, même à un niveau constant d'anesthésie profonde. Le produit du débit cardiaque par la pression artérielle ainsi que le débit cardiaque seul étaient les meilleurs prédicteurs de l'ordre de grandeur des modifications de la consommation d'ox ygène. 